\title{
DIAGNOSTIC INVESTIGATION BEFORE LAËNNEC
}

by

\section{GHARLES NEWMAN}

A SERIES of communications has appeared since $1957^{1,2,3}$, on how doctors began after 1819 to adopt the physical examination of patients as the principal method of making a diagnosis. 1819 is chosen as the date of the change because it was the date of the publication of Laënnec's book on instrumental auscultation. Although inspection, palpation and percussion (and indeed direct auscultation) were older methods, and had been used to some extent, it is surprising how little known they were, and how it was essentially the introduction of auscultation through the intermediary of a stethoscope which started the interest in physical examination and the resuscitation of the three older methods of investigation. The reason for this was that Laënnec not only described what he heard through the stethoscope, but also applied Morgagni's method of recording his findings and subsequently comparing them with what he found post mortem, thereby determining the state of internal organs from the physical signs they caused during life. This science turned out to be that of physical diagnosis, and led directly to the organ-pathology and Linnean identification of 'diseases', the two developments which became major contributions of the nineteenth century to Medicine.

The 'text-book' attitude to Medicine which this produced, by its great success, became so firmly established, so much the habit of mind of doctors, that it is difficult to remember that the investigation of patients had ever been different, or to imagine what it had been like. Therefore, to fill out and complete the brief review of the development of diagnostic technique, it would be worth while recording some typical examples of how diagnoses were made before i 819 .

It is not easy to find such records of pre-Laënnec days, because no case-notes older than 1823 have been preserved in any of the London Teaching Hospitals, the source most likely to provide the up-to-date material of any period. It is easy to surmise what the older records would be like, because until 1830 or even I 850 many, if not most, of the records of hospital patients were written by, or for, the residue of the pre-Laënnec generation, who were still the majority of the holders of senior posts and were certainly not enthusiastic about, and often barely tolerant of, these new-fangled notions. Their hospital records give the impression that they took a careful history from the patient, including details of what the-patient himself found in the way of lumps and other abnormalities, without in a surprising number of instances making any examination themselves. It was the patient who was complaining: very well, find out just 


\section{Diagnostic Investigation before Laënnec}

what the patient's complaint was, literally, and treat it. This attitude of mind is in striking contrast to the typical attitude of the early twentieth century, the attitude that it is what the clinician finds for himself that matters, and that any complaints by the patient which are not supported by physical signs are just 'functional' (or nonsense). It seems probable that the 1830 attitude is a survival from something older.

The Exhibition of Medical Records at the Royal College of Physicians in connexion with the 1958 Annual Meeting of the British Records Association provided an opportunity of studying the older records, which are widely scattered in provincial collections. To take an example from the seventeenth century, consider a clinical description by Dr. John Symcotts, who was Oliver Cromwell's physician.4 In $16{ }_{3} 6$ he writes:

\section{March 30. plenilunio}

Mistress Elizabeth Burgoyne, annorum 14, about 8 a clock at night fell into extreme headache, with pain of her left side, the shaking of an ague at first, afterwards very hot and generally distempered. The next day her pleuritical pain continued; she spit blood (though not much at a time). Hereupon she was let blood on the same side about 6 ounces; her pain of side abated, but the violent pain of her head continued. Her urine was a deep citrine, and changing. A clyster of cooling herbs and syrup of violets was given but brought away nothing. About 4 hours after bleeding she grew senseless, but taking some rest in the night she recovered her senses in the morning.

April 1. Her headache was great, the pain of her side not much troubling her but not removed. Her spittle raised from the lungs, bloody and blackish; hot, unquiet, feverish without intermission or remission. That night she slept unquietly.

April 2. I came to her in the morning; her pulse swift and high, she had many inequal distempers in the day; very weak, her tongue white, urine higher than before; full of groaning, her pains wandering and uncertain, sometimes most in her side, then about the left armpit, then most in her back. Upon the taking a common clysterine decoction with diacath. and red sugar without oil she had a great stool and found much ease, but spit bloody matter, and sometimes a foul dark green gobbet, sometimes pale fleshlike, and then with streaks of blood again. She slept slumbering that night.

April 3. Seeing she spit with streaks of blood still, I caused the liver vein of the right arm to be opened to 5 ounces. Her food was posset drink, which she liked well, and chicken broth made without herbs at all (for her stomach was extreme weak, loathing, foul) and sometimes beer warmed. Upon a clyster after the letting blood, she vomited, as the day before, yellow choler without mixture and some phlegm, had a large stool and had some ease; her spittle still not increasing, but as before, foul and bloody. Her water was now higher and quickly changing, and not supporting the clarity at all of itself.

April 4. (Her nose bled 2 ounces the next morning after the 2d bleeding.) Her urine higher than before; felt much pain about the armhole and shoulder, and her side was so sore (though not complained of) that she could not endure it to be touched; still weak, raised little more than before, but foul, discoloured and sometimes bloody. I gave her in the morning ol. communis, oz.ii, ros solis oz.i; she kept it without vomiting It wrought not. In the afternoon she took a clyster as before; she had a great stool upon it, and a worm of 3 quarters of a foot long, very slender, dead, empty, sharp at head and tail; was at this time in the greatest agony of all (she herself suggesting closely to her friends that she must die); her pulse very quick and weak, (but) upon refreshing she vomited much whatever was given and brought up some more sincere choler. After she was held up in bed, she vomited no more, nor complained of the pain of her stomach as before; slept well that night.

April 5. In the morning very cheerful, without all pains; complained not of weariness. I 


\section{Charles Newman}

gave her mercurium dulcis gr. 20. It gave a stool towards night but brought away no worms. At 5 a clock I returned home. The next day she was to abstain from physic, except wormseed and the like. She grew better and better still. The day following she took a purge of infusion of rhab., syr. Ang., etc. Convaluit, yet I prescribed lochsanum, the passulate electuary, and conserva cervina to be used after purging, to comfort the spirits and clear her lungs.

This girl must have had plenty of simple signs in her chest, if they had been looked for, because she presumably had lobar pneumonia, with the usual symptoms, the crisis on the seventh day, and possibly a lung abscess on the third. Dr. Symcotts observed her tongue, pulse, urine and sputum, though he recorded no deductions from any of these observations (they were probably too obvious to a seventeenth-century mind to need mention). He also noted that her side was tender when touched, so he may have examined her chest, though it is much more likely that he was told of this detail by those who had noticed it in moving the patient in bed. Dr. Symcotts was interested in the bleedings and purges to remove the humours, and in the round worm which he produced. He would probably have interpreted this as a product of the humours rather than the red herring it almost certainly was: the rest of the picture is too severe for Loeffler's syndrome.

This note is very like the sort of notes which were being written in hospitals in the first half of the nineteenth century; with minor changes in phraseology it could be mistaken for one. It is unusual for its time in being written in English, though Dr. Symcotts was ahead of his time (or falling short of the conventional dignities of his profession) in preferring English to Latin.

To give a more characteristic example, consider this:

1738. Jan. 5th. Robt. S. Pleuritis.

Nauta quinquagenarius fibrarum rigidarum; die 2 Jan. mane post somnum primum invasit Horripulatio \& frigus, cui succepit calor intensus \& dolor lateralis atrocissimus, Morbi die secundo sanguis detractus erat et varia remedia pectoralia exhibita. Die proximo bis iterata fuit venaest. et die morbi 4 iterum detractus erat sang, sed quoniam morbus nihilum cedebat, eodem die vocatus eram ante Meridiem. Morb. Phaen: Pulsus celer, plenus nequam admodum durus, dolor lateris dextris atrocissimus, inspirando valde auctus. Respiratio difficilis parva celer, tussicula propter dolorem suppressa cum sputo copioso. Praescripsi apozem* et linct. Vesperi, pulsus fuit minor, dolor adhuc intensissimus, respiratio sibilosa quia noluit tussire et materiam ex pulmonibus expellere. ideo sanguinem ex Brach. iterum detrahere praecipi qui antea fuit instar seri aquati sed nunc minus inflamatorius quoniam alvus varius responderat. etc.

(He became very weak and on the 8th January his feet and legs swelled, but 'tandem in mense Martio convaluit'.)

That was presumably a straightforward lobar pneumonia, and there are plenty of physicians still alive who can remember the days when lobar pneumonia was just like that, and, if it failed to kill a strong man, could immobilize him for three months with the associated heart-failure. The bleedings probably saved his life, and even if the diagnosis was incomplete, it was not altogether wrong, because the 'Pleuritis' was more conspicuous than the underlying

\footnotetext{
* Apozem means 'water boiled with herbs and spices; a decoction'. Littleton's Dictionary, 1684 .
} 


\section{Diagnostic Investigation before Laënnec}

pneumonia. And the signs of the latter would have been hard to find, even a good deal later than 1738 .

This was a fairly full note: probably a very full one for its time. Hospital notes of the same century were less detailed. Two typical case-histories from the Bath General Hospital ${ }^{5}$ are:

Wm. H. Mariner about 35 years of age lost the use of his limbs a year since in a voyage from the Coast of Africa to America he is sometimes better since his return and by the account sent of him from London appears to be a very proper object for the Bath Infirmary. J. Ditcher. Adm. I. May 1757, W. O. I.D. 20.Ap.57. Discharged mch. better 9th Nov. 57. a patient 190 days.

John S. in the year ' 47 was seized with a fever which left a violent pain in his hip with other rheumatic pains down his leg he was able to get his bread by his labour till within these 4 month and always finds relief on application of warm stupes to the part. Adm. I. May 57 . W.O. I.D. Dis. cured 29 th June 1757 a patient 60 days.

These notes are entered in a large volume consisting entirely of these brief histories, handsomely recorded. They are a cross between purely administrative records, like the 'Front Sheets' of modern case-notes, and Registrars' Clinical Summaries, but that would not prevent their being ward-records: actual casenotes were recorded in books until the nineteenth century, and it would be quite likely that no other record was kept, were it not for the absence of details of treatment, which is most unlike old case-notes, which recorded treatment in very full detail. The books which were taken round the wards are more likely to have been lost than the administrative registers kept in the office, so these notes should not be accepted as typical. A better source would be the notes written for certain by a doctor.

The commonest form of written description of clinical medicine in the old days was the written consultation. Doctors, or even patients, sent descriptions of cases to a chosen doctor, who returned his written opinion and advice. Dr. William Brownrigg of Carlisle was evidently much in request for this kind of consultation, and a typical example of his replies is: ${ }^{6}$

Consilium Nostrum pro Dno. Christian of the Isle of Man, Whitehaven 27 May 174 I.

Sir, I hope that your friend has given me so full \& just an account of your disorder that from this description I shall be enabled to form a right judgment concerning it. I observe what he relates of your having formerly for several years been subject to the gravell or nephritick complaints \& of your having for six months past been much afflicted with violent pains about your back and loins, \& having attentively considered these severall circumstances, and compared 'em with your present complaints, am induced to believe that some stone or stones have for a long time been lodged in the kidnies, etc.

In this instance it sounds as though the patient had asked a friend to call on Dr. Brownrigg and describe the symptoms and history at second hand. Dr. Brownrigg evidently found no difficulty in giving his opinion without seeing the patient, except for a doubt whether the history would be so full and just as the one he would have elicited himself. That he could not examine the patient was the least of his worries, and it does look as though doctors at that time must have underrated that aspect of diagnosis which derives from just looking at a 


\section{Charles Newman}

patient, his expression and behaviour, let alone the little indications which a disciple (or predecessor) of Sherlock Holmes could observe. They must have profited from such observation; but cannot have realized that they did so. Nor is this surprising: the 'Clinical instinct', the 'flair', the ability to make 'spot diagnoses', which used to be so popular in the not so distant days of medicine before laboratories and X-rays, was only the ability to notice things unconsciously, to draw conclusions, sometimes successfully, without knowing how it was done. The eighteenth-century physician must simply have been even more unaware of how he arrived at his conclusions. But in looking for evidence about the mental processes of an eighteenth-century physician, it is not to be expected that a written opinion on written information would contribute details of physical examination, so that a fairer and more complete piece of evidence about how doctors used to investigate their patients is to be sought in a complete clinical record made by the doctor in charge. Such a one is to be found in a note by Dr. Brownrigg of 1739 , apparently the report he gave to a consultant either before he saw the patient, or, quite likely, in order to get a written opinion on the case from an eminent man at a distance. The consultant was a Dr. Salkeld, and the report is headed: 'Mrs. W., Hydrops Pectoris, Rheumatismus, Cacheia, etc. To Dr. Salkeld', and reads:

Mrs. W., a gentlewoman aged about 49, of a full habit of body, having born six or seven children, for many years past very infirm, seldom enjoying a tolerable state of health, having been much afflicted with the rheumatism, gravel, asthma, dropsical swellings in her leggs \& several other disorders, for which she had taken a great variety of remedies.

About the latter end of May last when I first saw her, she complained of flying rheumatic pains and pains in the head, a continual pain and weight at her stomach, \& a very great difficulty in breathing which was much increased by motion, she breathed short but without any great noise or motion of the breast, and did not seem to be much troubled with a cough or phlegm[,] her leggs were also a little swelled.

For these complaints I ordered some pills with the Gumin \& Sap, \& Ar. Apozem with the Woods \& Rad Helenii Irid:- Glycyrrhiz: etc. as also a mixture with Oxym. Scill. These being constantly taken for some time did not seem to give her any relief. I therefore advised constant Riding in the Country Air, with a proper diet. She constantly found herself much refreshed by riding but the complaints still continued.

Towards the middle of June she told me that upon mounting on horseback she had for some time perceived her heart to move as if it were loose in her breast and that it gave her great uneasiness but settled after riding. This gave me some suspicion of an hydrops pectoris, a more strict enquiry being therefore made I was confirmed in my opinion so as not to doubt that this was the occasion of the asthma. For she not only perceived this fluctuation in her breast upon riding or any other quick motion, but also when she stooped forward. The load and continual pain which she said she felt at her stomach extended quite round from the Scrobiculus cordis to the Back, she describing [it] to be seated exactly in the parts where the diaphragm is connected to the ribs, and therefore seemed to be occasioned by the weighty pressure of the water upon the diaphragm. The asthma was also least in the evenings, and after she went to bed gradually increased, so that she seldom slept unless it was immediately after she gott into bed, and was often constrained to sit up in the nights and had constantly a great struggle for breath in the morning. The manner of breathing being short and without any great noise or motion of the breast seemed to shew that the difficulty proceeded from a compression of the lungs.

Thinking that this watery humour might possibly be expelled by diureticks I therefore prescribed a Tinct. Veneris made in Sal. Volat. Oleos, which I had experienced to be a powerful 


\section{Diagnostic Investigation before Laënnec}

diuretick deobstruant and which I gave at first in small quantities gradually increasing the dose. This promoted a plentiful discharge by urine by which she seemed to be much relieved.

But about the beginning of July catching cold she was seized with a fever \& a violent pain in her side, accompanied with an incepant cough, which complaints yielded to aperient decoctions, nitrous remedies cooling purges and fomentations.

For some time after she continued resolved to make no further use of remedies, but afterwards was desirous of having recourse to them again being wearied with her disorder which had increased so much that she breathed with the greatest difficulty.

On Aug. 6th at her desire a blister was therefore applyed which she said had formerly relieved when she was held in much the same way. I also ordered her some diuretick ingredients of the alcoline kind such as Rad. Raph. Sylv. Milleped. viv. Sal Absinth, infused in wine with gentian and other stomachicks. Observing that she grew very thirsty $\&$ that her tongue was very dry and black \& that she complained of a great heat and uneasiness after she took this remedy $I$ therefore desired her to make no further use of it. Being importuned to prescribe further I ordered her a strong purge with Rad. Mechoacant. rig. which had a much better effect than I expected. I therefore repeated it six or eight times by means of which means (sic) she was enabled to breath, with a great ease and freedom the last purge she took about the roth of $7 \mathrm{br}$. I then again tryed corroborants but found that they would not agree with her since they increased the heat \& thirst, dryness and blackness of the tongue still remaining.

Since that time I have only advised spirit of nitre or nitrous powders, she also takes a large dose of laudanum every night which makes her lye tolerably easy, although I have oft time dissuaded the use of it.

Since she left of the use of the purges her leggs and all the lower parts are swelled with water to a most enormous bulk, her belly is also much distended. She breathes with a little more ease than formerly, but says that she finds a great vacuity or emptiness about her breast which is very troublesome to her. The discharge by urine is greater than could be expected under these circumstances, all the other natural discharges have also been regular, except perhaps that of perspiration. Her pulse now is \& allways has been very good. She has had a tolerable good stomach till of late [in a different hand:] but tis now very bad.

[Reverting to original hand] These are the most material circumstances, although she is troubled with the haemorrhoids, lumbaga, rheumatica and many other complaints too tedious to mention.

18. 8bris. 1739. W.B.

[Then in the second hand again] Dr. Salkeld seemed to commend what had been done, and advised her to continue the use of the purges, taken one every other day using nitrous powders on the intermediate days, and entirely disapproved the use of laudanum; she took several purges but to no purpose, as they only weakened her, so that at length she was obliged to desist; and died about 2 ist December, having been affected with a delirium \& coma for about a week before her death.

This is a very interesting record in many ways, but from the point of view of diagnostic method the important things are that apart from feeling her pulse, looking at her tongue and presumably noticing the oedema (but he may have accepted her statement that 'all the lower parts are swelled ... and her belly is also much distended') he never examined her at all. On the contrary, when he was led to suspect, from the symptoms, that she had a pleural effusion, he did not look at her chest to see if she had, but confirmed his suspicion by eliciting further corroborative symptoms, even locating the site of the trouble by her 'describing it to be exactly where'. Physical examination counted for so little that he did not even argue anything from what he observed in the pulse or the tongue. Perhaps it would be more illuminating to say that he paid little 


\section{Charles Newman}

attention to them because at that time they led to only the vaguest conclusions. A rapid pulse and a dark urine depositing a precipitate implied 'inflammation'. So did the erythrocyte sedimentation rate, the other physical sign which they understood. They recognized it when shed blood, in clotting, formed a manifest cell-free layer on top, the 'buffy coat'. But it is important to remember that although both ancients and moderns use the word 'inflammation', they mean different things by it. To them it meant deleterious matter from within, from the body as a whole, settling in the part affected; to us it means the reaction of the part affected to something deleterious from without. It never occurred to them that when an 'issue' (a suppuration artificially induced by a seton or an embedded bean) in the arm was associated with an axillary abscess, the abscess was directly caused by the issue. Dr. Symcotts includes in his GaseBook a section 'Of too much confidence in issues alone without due purgatives'. The issue was meant to protect against disease by getting rid of the humours: that it was not adequate alone was proved by the settling of humours in the axillary glands, the humours ought to have been removed by auxiliary purges.

The doctors in those days were living in a different world. They paid no attention to physical examination because it would have been of no interest to them. Disease to them was a matter of the four humours, their settling in vital organs, the need to keep them on the move, to get rid of them by purging, etc., to counteract them by medicines of opposite temperature and nature, that is to say whether hot, cold, wet or dry. All this is a terrible lot of nonsense, but it would be a mistake for us to feel superior to the old physicians. In the first place, the theory of the four humours, once the fallacious basic theory was swallowed, was absolutely logical, and was capable of explaining much more than strict scientific theory can. Secondly, the old medicine was at least as satisfactory to the patient as modern medicine is: probably more so. It provided just those things which still send patients to bone-setters and homoeopaths. Even the most educated long for magic when they are ill. Thirdly, when one thinks of the horrors of medicine fifty years ago, total colectomies for 'focal sepsis', gallons of liquor arsenicalis to no purpose at all, the frank cruelty to neurotics, one cannot help wondering what will be said of our use of antibiotics, for instance, fifty years hence.

\section{ACKNOWLEDGEMENTS}

I would like to acknowledge for their help and kindness, Mr. L. M. Payne at the Library of the Royal College of Physicians and Mr. Kenneth Smith, the City Librarian at Carlisle, also the kind permission of the Carlisle Public Library Committee, Miss Joyce Godber and the Bedford County Record Office, Mr. A. Bond and the Bath Hospital Management Committee, and of Dr. F. N. L. Poynter and Mr. W. J. Bishop, for permission to quote the various records detailed in the References. 


\section{Diagnostic Investigation before Laënnec}

\section{REFERENCES}

1. Newman, C. Evolution of Medical Education in the 1gth Century. O.U.P., 1957, pp. 86-104.

2. Newman, G. 'Physical Signs at King's, King's Coll. Hosp. Gaz., 1958, xxxvin, 77.

3. Newman, C. 'Physical Signs in the London Hospitals', Med. Hist., 1958, n, 195.

4. Poynte R, F. N. L., and Bishop, W. J. (195I), A Seventeenth-Century Doctor and His Patients: John Symcotts, 1592?-1662, p. 60. Streatley Bedfordshire Historical Record Society. (CaseBook. MS. in Bedfordshire Record Office, X/125/13. Spelling and punctuation modernized.)

5. 'Case Histories, Bath General Hosp., $175^{-1}$ 758', MS. in Roy. Nat. Hosp., Bath.

6. Brownrigg, William. Case-Book, MS. in Carlisle Public Library (Jackson Lib., Tullie House. E. 104.), p. 29. 